\title{
Epidemia do vírus Zika: a mais nova emergência internacional
}

\author{
Ruth Minamisava ${ }^{1}$, Ana Karina Marques Salge ${ }^{2}$, Thaíla Corrêa Castral ${ }^{3}$, Sandra Maria Brunini de Souza4, \\ Romilda Rayane Godoi Souza ${ }^{5}$, Marília Cordeiro de Sousa ${ }^{6}$
}

${ }^{1}$ Enfermeira, Doutora em Medicina
Tropical. Professora Associada da
Faculdade de Enfermagem da Universidade
Federal de Goiás (FEN/UFG). Goiânia, GO,
Brasil. E-mail: minamisava@gmail.com.
${ }^{2}$ Enfermeira, Doutora em Patologia.
Professora Associada da FEN/UFG. Goiânia,
GO, Brasil. E-mail: anasalge@gmail.com.
${ }^{3}$ Enfermeira, Doutora em Ciências da
Saúde, Professora Adjunta da FEN/UFG.
Goiânia, GO, Brasil. E-mail:
thaccastral@gmail.com.

${ }^{4}$ Enfermeira, Doutorado em Enfermagem. Professora Associada da FEN/UFG. Goiânia, GO, Brasil. E-mail:

sandrabrunini@hotmail.com.

${ }^{5}$ Enfermeira. Discente do Programa de Pós-Graduação Enfermagem, nível Mestrado, da FEN/UFG. Goiânia, GO, Brasil. E-mail: romildarayane@gmail.com.

${ }^{6}$. Enfermeira. Discente do Programa de Pós-Graduação Enfermagem, nível Mestrado, da FEN/UFG. Goiânia, GO, Brasil. E-mail: maacsousa@hotmail.com.

Como citar esse artigo:

Antunes CMC, Rosa AS, Brêtas ACP. Da doença estigmatizante à ressignificação de viver em situação de rua. Rev. Eletr. Enf. [Internet]. 2016 [acesso em:_____ ] 18:e1136. Disponível em: http://dx.doi.org/10.5216/ree.v18.39890.
A infecção pelo vírus Zika é uma doença relativamente nova, com publicações limitadas a relatos de casos e investigações de surtos. Inicialmente foi descrita antes de 2007 na África e Ásia, posteriormente na Polinésia Francesa no Pacífico e, por fim, nas Américas, em 2015. O Brasil confirmou o primeiro caso de infecção pelo vírus Zika em março de $2015^{(1)}$ e, desde outubro, tem registrado aumento explosivo do número de recém-nascidos com microcefalia e também aumento de condições neurológicas, incluindo a síndrome de Guillain-Barré. A forte suspeita de a infecção pelo vírus Zika estar relacionada a essas manifestações é que levaram o Comitê de Emergência de Saúde Pública da Organização Mundial de Saúde declarar, no dia 10 de fevereiro deste ano, que a propagação do vírus é um problema emergencial de saúde pública internacional, ou seja, um evento extraordinário, grave, inesperado e que, potencialmente, requer uma ação internacional coordenada $^{(2-3)}$. A ausência de outra explicação para o aumento dramático de casos de microcefalia e da síndrome de Guillain-Barré, ambos concentrados em áreas recém-infectadas pelo vírus Zika, apoiam a recomendação de medidas agressivas para evitar/reduzir a infecção com o vírus Zika, especialmente entre mulheres grávidas e as em idade fértil.

No mesmo documento, a Organização Mundial de Saúde recomenda vigilância de casos de microcefalia e da síndrome de Guillain-Barré nas áreas de risco e pesquisas etiológicas desses eventos para determinar se a infecção pelo vírus Zika é causal e se há outros fatores de risco associados. As medidas de precauções adicionais são:

I. relacionadas à transmissão do vírus: vigilância epidemiológica, controle de vetor, medidas de proteção, informação e aconselhamento às mulheres grávidas e às que desejam engravidar; 
II. medidas de longo prazo: investimento em pesquisas voltadas para produção de vacina, diagnóstico acurado e tratamento, capacitação para cuidados com síndromes neurológicas e malformações congênitas;

III. medidas para viajantes: aconselhamento, desinfestação de aeronaves e de aeroportos e;

IV. compartilhamento de informações.

Alguns questionamentos têm sido feitos sobre a magnitude desta epidemia e a associação com microcefalia/desordens neurológicas ${ }^{(4-5)}$. É razoável ponderar que exista histórico sub-registro de microcefalia no Sistema de Informações de Nascidos Vivos do Brasil. Também é esperado que após o alerta nacional, o número de casos suspeitos se eleve. Ou seja, o aumento ou a implementação de vigilância sempre resulta em maior sensibilidade de detecção de casos suspeitos/notificados, com aumento de falso-positivos. Por essas razões, é possível dizer que parte do aumento nos casos de microcefalia notificados pode ser atribuível à intensa vigilância. O que é inimaginável é que a prevalência de microcefalia no nordeste brasileiro seja 10-20 vezes maior que a de outros países ${ }^{(6)}$. No momento, existem hipóteses que o vírus Zika possa ter papel etiológico e/ou fisiopatológico para esses eventos, usualmente raros.

O que nos parece inquestionável, é a gravidade da situação. Gestores de saúde não podem esperar evidências científicas de alto nível. Calma e prudência para avaliar é aconselhável. Evitar conclusões prematuras, idem. Entretanto, diante da potencial ameaça, temos o dever de, pelo menos, proteger as mulheres grávidas e seus fetos. A situação atual nos coloca muitos desafios a enfrentar, e parece lógico que o Brasil protagonize o início das ações. Reconhecemos em nossa história tanto o sucesso no combate à febre amarela no início do século passado como nossa recente ineficiência no combate ao mosquito Aedes aegypti para o controle da dengue e da chikungunya. É preciso criar, renovar e fortalecer estratégias de controle e de proteção efetivas.

O que temos de novo para vislumbrar melhor desfecho? Esforço internacional e financiamento de pesquisas para melhor combate ao vírus Zika e mobilização da população e dos profissionais de saúde frente à gravidade das doenças por ele provocadas e suas sequelas. Dificuldades? Muitas, sem dúvida. Além das dificuldades de controle do vetor já conhecidas no enfrentamento da dengue, circulam no Brasil outros mosquitos do gênero Aedes capazes de atuarem como vetores do vírus Zika ${ }^{(7-8)}$, criando novas possibilidades de transmissão e disseminação da infecção. Porém, é clara a emergência de ações para, no mínimo, reduzir o impacto e o receio das malformações congênitas nas futuras gerações.

O combate sem trégua ao mosquito deve ser o foco principal das nossas ações e isso implica em revermos nossas atitudes enquanto cidadãos. Não há espaço para o mero expectador. A batalha já iniciou e será longa! É chegada a hora de agir! É chegada a hora de toda a nação se mobilizar! É hora de mobilizar todo o país!

\section{REFERÊNCIAS}

1. Zanluca C, Melo VCA, Mosimann ALP, Santos GIV, Santos CND, Luz K. First report of autochthonous transmission of 
Zika virus in Brazil. Mem Inst Oswaldo Cruz [Internet]. 2015 [acesso em: 31 mar. 2016];110(4):569-72. Disponível em: http://dx.doi.org/10.1590/0074-02760150192.

2. World Health Organization [Internet]. Geneva: World Health Organization (SW) [acesso em: 31 mar. 2016]. WHO | Zika vírus. Fact sheet. Updated January 2016. Disponível em: http://www.who.int/mediacentre/factsheets/zika/en/. 3. World Health Organization [Internet]. Geneva: World Health Organization (SW) [acesso em: 31 mar. 2016]. Frequently asked questions on IHR Emergency Committee. Disponível em:

http://www.who.int/ihr/procedures/en ihr ec faq.pdf.

4. Butler D. Zika virus: Brazil's surge in small-headed babies questioned by report. Nature [Internet]. 2016 [acesso em: 31 mar. 2016];530(7588):13-4. Disponível em: http://www.nature.com/doifinder/10.1038/nature.2016.19259.

5. Tetro JA. Zika and microcephaly: causation, correlation, or coincidence? Microbes Infect [Internet]. 2016 [acesso em: 31 mar. 2016]. Disponível em: http://dx.doi.org/10.1016/j.micinf.2015.12.010. [Epub ahead of print].

6. Schuler-Faccini L, Ribeiro EM, Feitosa IM, et al. Possible Association Between Zika Virus Infection and Microcephaly Brazil, 2015. MMWR Morb Mortal Wkly Rep [Internet]. 2016 65(3):59-62. Disponível em:

http://dx.doi.org/10.15585/mmwr.mm6503e2.

7. Higgs S. Zika Virus: Emergence and Emergency. Vector-Borne Zoonotic Dis [Internet]. 2016 [acesso em: 23 fev. 2016];16(2):75-6. Available from: http://online.liebertpub.com/doi/10.1089/vbz.2016.29001.hig.

8. Marano G, Pupella S, Vaglio S, Liumbruno GM, Grazzini G. Zika virus and the never-ending story of emerging pathogens and transfusion medicine. Blood Transfus [Internet]. 2015 [acesso em: 23 fev. 2016]. Disponível em: http://dx.doi.org/10.2450/2015.0066-15. [Epub ahead of print]. 